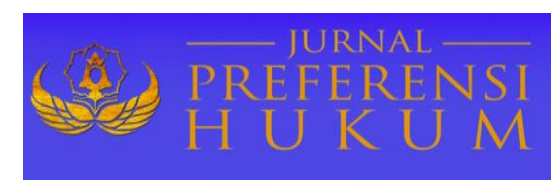

Jurnal Preferensi Hukum | ISSN: 2746-5039

Vol. 2, No. 1 - Februari 2021, Hal. 130-134| Available online at https://www.ejournal.warmadewa.ac.id/index.php/juprehum

DOI: https://doi.org/10.22225/jph.2.1.3057.130-134

\title{
DIVERSI TERHADAP PELAKU PEMBUANGAN OROK BAYI OLEH ANAK STUDI KASUS PENGADILAN NEGERI DENPASAR
}

\author{
Ni Putu Lalitha Candra Laksmi, A.A Sagung Laksmi Dewi, Diah Gayatri Sudibya \\ Fakultas Hukum Universitas Warmadewa, Denpasar-Bali Indonesia
}

\begin{abstract}
Abstrak
Anak sebagai pelaku tindak pidana juga akan mengalami proses hukum yang identik dengan orang dewasa yang melakukan tindak pidana, arti kata identik disini mengandung arti hampir sama, yang berbeda hanya jangka waktu serta cara penanganannya. Diversi adalah pengalihan atau pemindahan dari proses peradilan ke dalam proses singkat penyelesaian perkara, yaitu melalui musyawarah pemulihan atau mediasi. Penelitian ini bertujuan untuk mengetahuai pertimbangan hakim untuk memutuskan diversi terhadap anak sebagai pelaku tindak pidana dan sanksi pidana yang ditimbulkan terhadap anak sebagai pelaku tindak pidana pembuangan orok bayi Adapun pendekatan masalah yang dipakai terhadap penelitian ini, Penelitian ini menggunakan tipe penelitian hukum normatif yang disebut juga penelitian hukum doktrinal. Pendekatan masalah dalam penelitian ini dilakukan dengan mempergunakan metode pendekatan perundang-undangan dengan menelaah semua undang-undang dan regulasi yang bersangkut paut dengan peristiwa hukum yang terkait, pendekatan konseptual yang beranjak dari pandangan-pandangan dan doktrin-doktrin yang berkembang didalam ilmu hukum, dan pendekatan kasus. Pertimbangan Hakim dalam menetapkan Diversi terhadap pelaku pembuangan orok bayi oleh anak, kasus ini terdapat dalam perkara Nomor 18/Pid.SusAnak/2016/PN.Dps, anak diberikan kesempatan untuk memperbaiki kesalahan dan dikembalikan ke orang tuanya untuk dijaga dan dibimbing serta untuk dibina agar anak tidak melakukan lagi perbuatan tersebut.
\end{abstract}

Kata Kunci: Diversi, Pembuangan Orok Bayi; Tindak pidana, Proses Hukum

\begin{abstract}
Children as perpetrators of criminal acts will also experience legal processes that are identical to adults who commit criminal acts, the meaning of the word identical here means almost the same, only the timeframe and the method of handling it are different. Diversion is a diversion or transfer from the judicial process into a short process of settlement of cases, namely through deliberation for recovery or mediation. This study aims to find out the judges' considerations to decide on diversion against children as perpetrators of criminal acts and criminal sanctions inflicted on children as perpetrators of the crime of removing baby babies. doctrinal law. The approach to the problem in this research is carried out by using the statutory approach method by examining all laws and regulations related to related legal events, a conceptual approach that departs from the views and doctrines that develop in legal science, and approaches. case. Judges considerations in determining Diversion against the perpetrators of disposal of babies by children, this case is in case Number $18 /$ Pid.SusAnak / 2016 / PN.Dps, children are given the opportunity to correct mistakes and return them to their parents to be guarded and guided and to be nurtured so that the child does not do the act anymore.
\end{abstract}

Keywords: Diversion, Baby Carriage Disposal; Crime, Legal Process

\section{PENDAHULUAN}

Negara Indonesia merupakan suatu Negara Hukum, hal ini dapat dilihat dari Pancasila memiliki peraturan yang berbentuk Undang-Undang Dasar Negara Kesatuan Republik Indonesia Tahun 1945, merupakan peraturan yang berfungsi mengatur tatanan hidup bermasyarakat yang ada dari hukum dan bertujuan untuk menciptakan ketertiban dan keamanaan, serta memiliki dampak terhadap sebuah aktivitas serta tingkah laku semua lapisan masyarakat yang harus tepaat dengan nilai hukum positif Indonesia. Sanksi hukuman di Indonesia menjadi panduan bagi seluruh masyarakat karena sanksi hukuman dianggap sebagai alaat untuk memberantas berbagai macam tindakan kriminal, dimana saat ini kejahatan semakin berkembang pesat dimana aparat hukum di haruskan untuk menuntaskan berbagai permasalahan hukum dan apa yang menjadi fungsi hukum adalah tidak terjadinya kekaburan hukum serta keadilan di mata hukum yang berakibat tercapainya kemanfaatan dapat tercapai, yang utama dalam kejahatan diperbuat anak-anak (Prasetyo, 2011; Sudanto, 2018). 
Sama seperti orang dewasa, anak juga dapat dikatakan sebagai pelaku atau terdakwa dari adanya kejahatan, mereka juga akan melewati proses hukum yang berlaku hampir sama dengan orang dewasa yang melakukan suatu tindak pidana. Dalam hal menangani dan menghadapi suatu proses peradilan anak yang terlibat tindak pidana, jadi tahap pertama yang tidak dapat dilupakan adalah dengan mengetahui dan memahami kedudukannya sebagai anak dari semua sifat dan ciri-ciri yang khusus, maka dengan demikian orientasi akan bertolak dari konsep perlindungan terhadap anak dalam suatu proses cara penanganannya sehingga hal ini akan terdapat pada konsep kesejahteraan anak dan kepentingan anak tersebut. Proses hukum dalam penanganan anak sangat memerlukan kasih sayang, perhatian serta perlindungan yang khusus pada anak dalam upaya memberikan perlindungan hukum terhadap anak yang berhadapan dengan hukum.

Dalam hal ini anak termasuk bagian dari warga Negara, yang harus mendapatkan perlindungan sebab mereka akan menjadi generasi Bangsa dimasa depan yang akan melanjutkan kepemimpinan bangsa Indonesia (Darmini, 2019). Setiap anak yang ada di negara ini atau dimanapun, disamping wajib mendapatkan pendidikan formal seperti sekolah, anak juga wajib mendapatkan pendidikan etika dan moral yang akan membuat mereka dapat tumbuh dan berkembang menjadi sosok yang berguna bagi Nusa dan Bangsa. Maka dalam kasus ini terdapat peraturan yang terkait seperti UU Sistem Peradilan Pidana Anak, dimana disitu terdapat pengertian Diversi dan Restorative Justice. Diversi adalah suatu pengalihan penyelesaian kasus-kasus anak yang diduga terlibat dalam suatu tindak pidana tertentu, yang proses penyelesaiannya dari proses pidana formal ke penyelesaian damai atau yang sering disebut mediasi, yang terjadi antara tersangka dengan terdakwa dan diberikan fasilitas oleh keluarga, pembimbing kemasyarakatan anak, polisi, jaksa atau hakim, masyarakat, yang bersangkutan dalam kasus tersebut. Dengan adanya diversi ini anak harus lebih dibimbing dan dibina, sehingga anak-anak dapat tumbuh dan berkembang sebagai anak pada umumnya yang normal, sehat dan cerdas seutuhnya. Akan tetapi, si anak akan mengalami dan melewati situasi sulit yang akan membuatnya berfikir untuk melakukan suatu tindakan yang melanggar norma hukum. Meskipun demikian, anak-anak yang melanggar hukum tidaklah patut untuk dihukum dan kemudian dimasukkan ke dalam penjara.

Penelitian ini bertujuan untuk mengetahui dan menjelaskan pertimbangan Hakim untuk memutuskan Diversi terhadap anak sebagai pelaku tindak pidana dan menganalisis sanksi pidana yang ditimbulkan terhadap anak sebagai pelaku tindak pidana pembuangan orok bayi.

\section{METODE PENELITIAN}

Penelitian ini menggunakan tipe penelitian hukum normatif yang disebut juga penelitian hukum doctrinal (Soekanto \& Mamudji, 2006). Pendekatan masalah dalam penelitian ini dilakukan dengan mempergunakan metode pendekatan perundang-undangan dengan menelaah semua undang-undang dan regulasi yang bersangkut paut dengan peristiwa hukum yang terkait, pendekatan konseptual yang beranjak dari pandangan-pandangan dan doktrin-doktrin yang berkembang di dalam ilmu hukum, dan pendekatan kasus. Sumber bahan hukum dalam penelitian ini adalah:

1. Bahan hukum Primer, yaitu: bahan hukum yang berpusat pada Keputusan Presiden, Peraturan Mahkamah Agung, UU tentang Kekuasaan Kehakiman, UU tentang Sistem Peradilan Pidana Anak, UU tentang Kesejahteraan Anak, UU tentang Perlindungan Anak.

2. Bahan Hukum Sekunder yaitu: bahan-bahan hukum yang diperoleh dari pengkajian kepustakaan, seperti: buku, jurnal-jurnal hukum, surat kabar, internet, dan pendapat para ahli.

\section{HASIL DAN PEMBAHASAN}

\section{Pertimbangan Hakim dalam Memutuskan Diversi Terhadap Pelaku Pembuangan Orok Bayi oleh Anak}

Diversi merupakan salah satu cara pengalihan penyelesaian perkara yang dilakukan oleh anak-anak yang dituduh melakukan suatu perbuatan pidana tertentu, dengan melakukan penyelesaian perkara pidana secara umum berubah menjadi penyelesaian dengan cara damai atau sering disebut mediasi, yang terjadi antara tersangka dengan terdakwa dan diberikan fasilitas oleh keluarga, pembimbing kemasyarakatan anak, polisi, jaksa atau hakim, masyarakat, yang bersangkutan dalam kasus tersebut. Secara gramatikal atau kata yang berubah-ubah sesuai dengan konteks dan pemakaiannya pengertian Diversi adalah pengalihan perkara anak. Dimana pelaksanaan Diversi di latarbelakangi dari adanya 
keinginan agar terhindar dari sesuatu yang buruk terhadap mental anak, serta mengganggu perkembangan anak dengan keterlibatannya dengan proses peradilan pidana anak.

Chris Graveson juga memberikan pendapat bahwa, diversi merupakan suatu proses yang telah diakui secara global, karena hal tersebut merupakan cara terbaik didalam proses menyelesaikan perkara mengenai anak yang sedang berhadapan dengan proses hukum (Juliasari, 2020). Tindakan campur tangan yang dilakukan oleh suatu lembaga atau badan terhadap sebuah permasalahanyang terjadi di antara dua pihak atau beberapa pihak sekaligus akan merugikan salah satu pihak yang sedang bermasalah, sama halnya terhadap anak yang sedang berhadapan dengan Hukum yang sangat luas dan berbagai jenis, namun banyak mengalami penekanan pada penahanan dan penghukuman, tidak peduli seberapa ringannya pelanggaran yang dilakukan oleh anak tersebut atau betapa mudanya usia anak-anak tersebut (Hamzah, 2010).

Tujuan dilakukannya Diversi berdasarkan UU Sistem Peradilan Pidana Anak adalah sebagai berikut: 1) Mendapatkan perdamaian terhadap korban dan anak sebagai pelaku, 2) Mengakhiri perkara anak diluar proses peradilan dengan cara musyawarah atau mediasi, 3) Menjauhi anak dalam perampasan kemerdekaan untuk masa depannya, 4) Mengajak seluruh rakyat ikut serta seperlunya, dan 5) Mendidik untuk menumbuhkan rasa pertanggung jawaban kepada anak. Hal ini menimbulkan rasa untuk bersama mendapatkan jalan keluar yang seadilnya dengan memperhatikan pemuliihan kembali kepada anak agar psikis dan mental dalam keadaan semula dan bukan merupakan suatu pembalasan. Menurut Liebmann, adanya prinsip-prinsip awal dari restorative justicie adalah sebagai berikutnya: a) Mengutamakan penyembuhan dan dukungan korban, b) Yang menjadi pelaku pelanggaran agar bertanggung jawab atas apa yang dilakukannya, c) Diskusi antara korban dan pelaku untuk mencapai pemahaman yang adil, d) Melakukaan upaya untuk meletakkan secara benar kerugian dan keuntungan yang ditimbulkan, e) Pelaku pelanggaran harus sadar terhadap bagaimana caranya menghindari kejahatan dimasa depan, f) Rakyat umum turut membantu dalam menggabungkan antara dua belah pihak, yaitu korban dengan pelaku (Yuniar Ariefianto, 2014).

Penyelesaian melalui diversi ini memiliki suatu ruh yang sama dengan penyelesaian sengketa melalui Restroactive Justice, yaitu merupakan penyelesaian perkara tindak pidana dengan cara melibatkan seorang pelaku atau korban, dan juga pihak-pihak lain yang terkait, hal ini bertujuan untuk bersama-sama mencari penyelesaian yang adil atau tidak berpihak, dengan menekankan dengan adanya pemulihan kembali pada keadaan semula dan bukan dengan cara melakukan pembalasan. Sehingga berdasarkan penetapan No.18/Pid.Sus-Anak/2016/PN.Dps, dimana kasus ini meliputi kasus Pembuangan Orok Bayi Oleh Anak berumur 14 Tahun yang masih duduk di bangku SMP. Dimana dalam suatu penetapan Pengadilan, ada beberapa pertimbangan Hakim untuk memberikan penetapan ke Pengadilan seperti halnya penetapan No.18/Pid.Sus-Anak/2016/PN.Dps. Maka dari itu pertimbangan hakim dalam menetapkan kasus Diversi ini memang sesuai ketentuan-ketentuan dan norma hukum yang berlaku.

Hakim dalam melakukan pertimbangan memiliki beberapa kriteria yang dapat diuraikan sebagai berikut:

1. Pertimbangan Yuridis atau Kepastian Hukum.

Dalam hal ini adanya pertimbangan hakim yang sebagian besar didasarkan pada faktor-faktor yang terungkap di dalam persidangan dan dengan peraturan perundang-undangan yang telah ditetapkan sebagai hal yang harus termuat di dalam putusan atau penetapan. Dasar dari pertimbangan yuridis ini, adanya ketentuan dalam Hukum Pidana, dimana ketentuan tersebut akan digunakan sebagai panduan dalam menimbang dan memutus perkara yang di lakukan oleh anak. Pertimbangan Yuridis ini lebih berpacu dengan pemikiran hakim dalam memutus suatu perkara (Widodo, 2008).

Dari sisi Yuridis ini sudah terdapat kepastian seseorang dianggap dewasa apabila sudah berumur 17 Tahun keatas atau sudah menikah karena dalam kasus penetapan No: 18/Pid.susAnak/2016/Pn.Dps ini anak berusia 14 Tahun belum memenuhi kreteria dewasa dan merupakan korban dari lemahnya pengawasan orang tua, sedangkan pembuangan atau pengguguran merupakan tindak pidana.

2. Pertimbangan Non Yuridis.

Hakim dalam melakukan suatu pertimbangan yang bersifat non yuridis ini, sangat dibutuhkan karena timbulnya masalah tanggung jawab hukum yang harus dilakukan oleh anak dibawah umur tidaklah cukup hanya berdasarkan pada segi normatif fisik kerugiannya saja, tetapi faktor- 
faktor lainnya seperti faktor intern dan ekstern yang sangat melatar belakangi si anak dalam melakukan kejahatan atau kenakalan, namun juga harus dipertimbangkan secara arif oleh Hakim yang mengadili kasus terhadap anak.

Adapun hal-hal meringankan dan memberatkan didalam Diversi menurut penetapan No: 18/Pid.susAnak/2016/Pn.Dps, adalah klien merupakan anak yang bertanggungjawab, hal ini dibuktikan dengan memberikan keterangan sesuai dengan apa yang dilakukannya dan dapat memnuhi panggilan pemeriksaan secara koopratif. Klien merasa bersalah dengan dirinya sendiri, ia juga telah menyesali perbuatannya, klien juga adalah anak yang rajin dan tidak pernah bersalah sebelumnya. Sedangkan hal yang memberatkan pelaku diduga melakukan tindak pidana kekerasan terhadap anak atau Pembuangan orok bayi, sebagaimana diatur dalam Pasal tentang perlindungan anak, sementara sanksi bagi seseorang yang melanggar pasal diatas ditentukan dalam Pasal tentang perlindungan anak. Dengan adanya Diversi Sistem Peradilan Pidana Anak, hal ini sangat bermanfaat bagi anak terutama agar terhindar dari efek negatif terhadap perkembangan dan jiwa sianak oleh keterlibatannya dalam Proses Peradilan pidana, serta dapat memberikan dukungan lebih bagi anak supaya menjadi sosok baru dan bersih dari catatan kejahatan dan tidak menjadi residivis karena itu akan merusak masa depan si anak.

\section{Sanksi Pidana yang Ditimbulkan terhadap Anaksebagai Pelaku Pembuangan Orok Bayi}

Adapun sanksi pidana yang melatar belakangi terjadinya pembuangan orok bayi oleh anak dan hakim memutuskan Diversi seperti contoh kasus perkara yang terjadi di Pengadilan Negeri Denpasar Penetapan Nomor: 18/Pid.Sus-Anak/2016/PN DPS. Maka pendapat penyidik adalah sebagai berikut:

1. Bahwa penyidik telah melimpahkan berkas perkara Penetapan Nomor: 18/Pid.SusAnak/2016/PN DPS dan barang bukti kepada Jaksa Penuntut Umum dengan persangkaan Pasal diatas.

2. Bahwa didalam Pasal 3 Ayat 1, dan 2, PP tentang pedoman perlaksanaan Diversi dan penanganan anak yang belum berumur 12 Tahun.

Dengan demikian, syarat untuk pelaksanaan diversi yang terdapat dalam penetapan No: 18/Pid.Sus-Anak/2016/PN.DPS telah terpenuhi sebagai berikut:

1. Diversi dilakukan dalam tindak pidana yang dilakukan anak diancam dengan diancam dengan pidana penjara dibawah 7 tahun, terhadap ANAK sebagai pelaku yang terdapat dalam penetapan No: 18/Pid.Sus-Anak/2016/PN.DPS didakwa dengan dakwaan alternatif dimana salah satu dari dakwaan tersebut yaitu Pasal 181 KUHP diancam dengan pidana penjara dibawah 7 tahun dan tindak pidana yang dilakukan anak bukan merupakan pengulangan tindak pidana;

2. Menyangkut persyaratan anak yang wajib dilakukan diversi adalah anak yang telah berumur 12 tahun tetapi belum berumur 18 tahun, bahwa ANAK yang sebagai pelaku pembuangan orok bayi tersebut berumur 14 tahun, dan merupakan seorang pelajar kelas III SMP di salah satu Sekolah Menengah Pertama yang ada di Denpasar.

3. Bahwa peraturan MA RI No.4 Thn 2014 Pasal 3 mengenai pedoman pelaksanaan diversi didalam sistem peradilan anak.

4. Bahwa menurut pendapat penyidik, kedudukan ANAK dalam Penetapan Nomor: 18/Pid.SusAnak/2016/PN.DPS selain sebagai pelaku adalah juga sebagai korban dari pergaulan bebas karena adanya kesempatan untuk melakukan hubungan seksual diusia dini akibat minimnya pengawasan dan bimbingan orang tua.

5. Bahwa penyidik dalam hal ini berkesimpulan: menyetujui proses Diversiterhadap perkara dalam Penetapan Nomor: 18/Pid.Sus Anak/2016/PN.DPS dengan permohonan agar anak dikembalikan kepada orang tua untuk mendapatkan bimbingan dan pengawasan berkerjasama dengan pembimbing kemasyarakatan BAPAS Denpasar dan P2TP2A Denpasar untuk melakukan konseling psikologi terhadap anak.

\section{KESIMPULAN DAN SARAN}

\section{Kesimpulan}

Pertimbangan hakim dalam memutuskan diversi terhadap pelaku pembuangan orok bayi oleh anak yang terdapat dalam (Penetapan Nomor: 18/Pid.Sus-Anak/2016/PN.Dps) memiliki 2 kriteria yaitu: (1) Pertimbangan Yuridis atau kepastian hukum, meliputi beberapa hal: Dakwaan Jaksa Penuntut Umum, 
Tuntutan pidana, Keterangan Saksi, Keterangan Terdakwa, Barang-barang Bukti, dan Pasal-pasal yang terdapat dalam Undang-undang. (2) Pertimbangan Hakim yang bersifat Non Yuridis, terdapat pada Aspek sosiologis, aspek psikologis dan aspek kriminologi. Kemudian, sanksi pidana merupakan suatu hukum mengenai sebab akibat, yang mana sebab adalah kasusnya, sedangkan akibat adalah hukumnya. Seseorang yang terkena akibat akan memperoleh sanksi baik masuk penjara, ataupun terkena hukuman lain dari pihak berwajib. Sedangkan didalam (penetapan No: 18/Pid.SusAnak/2016/PN DPS), penyidik melimpahkan sanksi terhadap anak yang melakukan pembuangan orok bayi dengan persangkaan sebagai berikut: Pertama: Pasal 76C Jo, pasal 80 ayat (3) dan ayat (4) dalam UU RI No: 35 Thn 2014 , tentang Perlindungan Anak. Kedua: Pasal 45A Jo Pasal 77A UU RI No: 35 Thn 2014, mengenai perlindungan pnak. Ketiga: Pasal 181 Kitab Undang-Undang Hukum Pidana.

\section{Saran}

Melalui penelitian ini diharapkan peran kedua orang tua, keluarga dan lingkungan sekitarnya untuk lebih mengawasi dan membimbing, serta lebih menyempatkan waktunya untuk selalu berada disisi anak-anaknya atau sekedar berdiskusi tentang apa saja yang dirasakan oleh si anak dan dalam kondisi apapun, sehingga remaja tidak dapat terjerumus untuk melakukan hal-hal yang menyimpang, terutama jangan sampai melakukan hubungan suami istri tanpa memiliki ikatan perkawinan atau belum kawin atau kegiatan asusila lainnya. Untuk upaya yang telah dilakukan oleh Hakim dan aparat penegak hukum lainnya yang berkaitan dengan kasus ini, diharapkan agar dapat memberikan sosialisasi lebih jelas mengenai akibat hukum dari kenakalan remaja terutama yang berujung pada pembuangan orok bayi oleh anak.

\section{DAFTAR PUSTAKA}

Darmini. (2019). Pelaksanaan Diversi pada Sistem Peradilan Anak. Qawwãm, 13(1), 43-63.

Hamzah, R. (2010). Kajian Yuridis tentang Konsep Diversi. Malang: Bayu Media Publishing.

Juliasari, T. (2020). Kendala Penyelesaian Perkara Anak Melalui Diversi (Studi Kasus Putusan Nomor Put.No.1/Pidsus-Anak/2015 Pengadilan Negeri Mempawah ). E-JOURNAL FATWA HUKUM FACULTY OF LAW UNIVERSITAS TANJUNGPURA, 3(3).

Prasetyo, B. (2011). Sanksi Hukum terhadap Pelaku Kejahatan dengan Hypnosis. DIH, Jurnal Ilmu Hukum, 7(13), 35-44.

Soekanto, S., \& Mamudji, S. (2006). Penelitian Hukum Normatif Tinjauan Singkat. Jakarta: Rajawali Pers.

Sudanto, A. (2018). Penerapan Hukum Pidana Narkotika di Indonesia. ADIL: Jurnal HukumJurnal Hukum, 7(1), 137-161.

Widodo. (2008). Prisonisasi Anak Nakal: Fenomena dan Penanggulangannya. Yogyakarta: Aswaja Pressindo. Yuniar Ariefianto. (2014). Penerapan Restoratif Justice Dalam Penyelesaian Kasus Kecelakaan Lalu Lintas. Universitas Brawijaya.

Keputusan Presiden No.36 Tahun 1990 Peraturan MA No.04 Tahun 2014

UU No.48 Thn.2009 tentang Kekuasaan Kehakiman

UU No.11 Thn.2012 tentang Sistem Peradilan Pidana Anak

UU No.04 Thn. 1979 tentang Kesejahteraan Anak

UU No.35 Thn.2014 tentang Perlindungan Anak 